\title{
DE LANDBOUW BIJ DE BOSNEGERS VAN DE MAROWIJNE
}

\author{
DOOR
}

\author{
D. C. Geijskes ${ }^{1}$ )
}

\section{INLEIDING}

Wanneer men in de kleine maatschappijen komt van de bosbewoners, die in de binnenlanden van Suriname leven, dan ziet men bij onderzoek spoedig de basis, waarop de instandhouding van zulke gemeenschappen berust. De strijd om het bestaan bij de primitieve volken omvat de voedselvoorziening en de weerstand die kan worden geboden tegen ziekte en plagen. Deze twee factoren bepalen uiteindelijk het geboorte overschot, dat als resultante de bestaansmogelijkheid uitdrukt.

$\mathrm{Bij}$ de Bosnegers zien we in de loop der jaren een toeneming van de bevolking, een vooruitgang dus, ondanks de tegenwerking van de natuur. Maar deze vooruitgang schept nieuwe problemen. Het was tijdens de Medisch-Wetenschappelijke Expeditie NAAR DE ZUIDGRENS VAN SURINAME, gehouden van Februari tot Juli 1952, dat wij in aansluiting op het medisch onderzoek bij het verzamelen van gegevens over de ,huishouding" van de Bosnegers van de Marowijne en de Tapanahoni, vooral op het probleem van de voedselvoorziening en van de voeding zelf stuitten. Het heeft weinig zin om alleen aandacht te schenken aan de medische zorg, wanneer daarbij niet tegelijkertijd pogingen worden aangewend, om de voeding te verbeteren.

Een voornaam onderdeel van de voedselvoorziening vormt de landbouw. Deze levert de Bosnegers het meeste, maar niet het beste voedsel op. Daarnaast voorzien enkele bosproducten in de behoefte aan spijsvetten, terwijl de jacht en de visvangst de dierlijke eiwitten moeten opbrengen.

1) Gouvernements-bioloog bij het Departement van Binnenlandse Zaken, Paramaribo. 
De landbouw van de Bosnegers is echter door het verkwistende landgebruik een aangelegenheid geworden, welke dringend de aandacht van de overheid vraagt. Tot nu toe is hieraan weinig aandacht besteed, maar wanneer men het binnenland van Suriname tot ontwikkeling wil brengen, zal ook dit probleem moeten worden bekeken.

De hier verstrekte gegevens belichten de landbouw bij de Paramaccaners en de Aucaners aan de Marowijne en de Tapanahoni. $\mathrm{Zij}$ zijn bijeen gebracht tijdens genoemde Medische Expeditie en gedurende een reis naar de Tapanahoni in October 1952. De feiten hebben dus in de eerste plaats betrekking op de Marowijne, maar zij gelden in hun algemeenheid stellig ook voor de andere rivieren waarlangs Bosnegers wonen. Het is een typisch Surinaams probleem, samenhangende met de omstandigheid, dat in de verre binnenlanden gedurende honderden van jaren door de Bosnegers op dezelfde wijze is gewerkt, onafhankelijk van het leven in het geciviliseerde kust-gebied en vrijwel geheel buiten de belangensfeer van het Gouvernement.

\section{HET GRONDJESSYSTEEM}

Voor het planten van landbouwgewassen legt de Bosneger z.g. kostgrondjes aan. Hieronder verstaat men opengekapte stukken in het oerwoud, waarop de gewassen worden geteeld. De grondjes liggen langs de rivieren op hogere vlakke terreinen, meestal terrassen, die bij hoogwater niet onderlopen, of, bij gebrek aan zulke terreinen, op de hellingen van heuvels. $\mathrm{Zij}$ zijn min of meer cirkelvormig en hebben een oppervlakte van een halve tot anderhalve hectare.

In de grote drogetijd (October, November) kappen de mannen de grondjes open. Twee tot drie weken daarna wordt het gevelde bos verbrand; men ruimt de kleinere takken op, maar laat de stammen liggen. De grond wordt niet bewerkt. Zodra de regens van de kleine regentijd inzetten, gaat men planten en zaaien. Deze planttijd valt in December en Januari. De Bosnegervrouwen (want alleen de vrouwen doen het verdere werk) planten nu allerlei gewassen tegelijkertijd op eenzelfde grondje. De gewassen. komen dus verspreid door elkaar te staan of worden hoogstens pleksgewijs aangelegd. De oogsttijden van deze gewassen hebben een zekere successie. Er zijn twee groepen te onderscheiden, nl. (1e) de vlug groeiende ,,eenjarige" gewassen en (2e) de langzamer groeiende meerjarige gewassen. 
Tot de eerste behoren:

mais, wordt na drie maanden (in Februari en Maart) geoogst;

watermeloen, idem;

oker, levert na drie maanden (Februari, Maart) en nog een tijd daarna eetbare vruchten;

pompoen, geeft na vier maanden (April) en daarna rijpe vruchten;

pinda en agobo, bloeit na drie maanden (Februari, Maart) en levert na vijf maanden (Mei, Juni) product;

bongila, idem;

tabak, is na 4-5 maanden plukrijp, bloeit na 7 maanden;

rijst, is na 4-5 maanden (Mei-Juli) rijp.

Tot de tweede categorie behoren de meerjarige gewassen:

suikerriet, wordt na 5-6 maanden reeds gekapt, maar de stoelen worden tot twee jaren en langer aangehouden;

cassave, de knollen worden na 7 maanden en langer geoogst;

tajer, napi, yams en pataten, worden (behoudens uitzonderingen, zie aparte lijst) na 8-10 maanden (Augustus tot November) geoogst, maar ook doorlopend daarna;

ananas, is na 9 maanden rijp;

bacove, na 10 maanden rijpe vruchten, de stoelen worden aangehouden;

bananen, na 10-12 maanden geoogst en verder doorlopend van de nieuwe stoelen.

Het voordeel van deze plantwijze is, dat de grondjes het gehele jaar door iets opleveren. Een nadeel is echter, dat elk jaar nieuwe grondjes moeten worden aangelegd. Op deze wijze zijn voor een gezin steeds verscheidene grondjes in gebruik. In het eerste jaar levert het grondje vooral de vlugst groeiende producten en een gedeelte van de meerjarige gewassen op; in het tweede jaar oogst men voornamelijk cassave, bacove, bananen en suikerriet, terwijl in het derde jaar nog wat ananas, bananen en suikerriet wordt afgeoogst.

Daarna geeft men het grondje prijs aan het opschietende secundaire bos (kapoeweri), hier ,,kauwé” genoemd, en aan de onkruiden, zoals het snijgras „,baboen nefi” (Scleria secans), die een verder doorgroeien van de cultuurgewassen belemmeren.

Dit systeem van grondjes kappen vraagt veel land. Het is een ernstige roofbouw die alleen toegepast kan worden wanneer voldoende vrij land"ter beschikking ligt. Pas na vele jaren kan men op een zelfde stuk bos voor de aanleg van een nieuw grondje terugkomen, afhankelijk van het herstel van het bos, meer in het bijzonder van de bouwkruin.

Bij de Bosnegers van de Marowijne geldt de regel, dat elk gezin voor zich zelf zorgt. De man kapt het grondje open met hulp van familieleden of vrienden, welke tegen verstrekking van voeding gedurende deze tijd worden aangenomen. Heeft de man 
één vrouw, dan worden gewoonlijk twee grondjes per jaar gekapt; heeft hij meer dan één vrouw, dan kapt hij voor elke vrouw twee grondjes open.

Een kapitein van een dorp legt zelf zijn grondje aan, geholpen door zijn dorpelingen. De Granman echter werkt niet zelf, maar laat, afhankelijk van zijn vrouwenaantal, door familie en andere helpers grondjes openleggen, tegen verstrekking van mondkost voor de werkdagen. De producten van de grondjes van een gezin vormen geen gezamenlijk bezit, maar de vrouw laat haar rechten gelden voor de opbrengst van één grondje, terwijl de man aanspraak maakt op die van het andere grondje. Er wordt dus onderscheid gemaakt tussen het agrarisch bezit van de vrouw en dat van de man.

\section{DE MIERENPLAAG EN DE MIEREN-KAPOEWERI}

In de landbouw van de Bosnegers speelt de mierenplaag een belangrijke rol. De draag- of parasolmieren (Atta sexdens en Atta cephalotes) zijn door bladroof zeer ruïneus in de planterij. De eerstgenoemde soort is in de binnenlanden van Suriname de grootste boosdoener. Vooral cassave heeft van deze miersoort veel te lijden, maar ook mais, tajer en bananen worden afgevreten. Deze plaag is zo ernstig, dat het openkappen van een nieuw grondje mede bepaald wordt door het ter plaatse voorkomen van de nesten van deze mieren. Normaal liggen deze nesten in het oerbos vrij ver uiteen, maar zodra de gewassen van de grondjes onder het bereik van de mieren komen, groeien de nesten welig op. Bovendien vormen de mieren juist tegen de planttijd talrijke geslachtsdieren, die door de opengelegde terreinen een gunstige gelegenheid krijgen tot uitzwermen en het stichten van nieuwe kolonies. De draagmieren zijn hier dus „,Kulturfolger”.

Door deze mierenplaag is het meestal voor de Bosnegers niet mogelijk om langer dan twee tot drie jaren achtereen verlengstukken aan de bestaande grondjes te kappen. Immers, de kapoeweri van de verlaten stukken fungeert dan als schuilplaats voor de jongere mierennesten, en men sleept als het ware de mierenplaag achter zich aan. Mierenbestrijding vindt niet plaats en de Bosneger is door onmacht gedwongen het veld te ruimen. Deze vlucht voor de mieren bestaat in het zoeken van nieuwe gronden verder het bos in, of indien dit om bepaalde reden niet meer mogelijk is, in het bezetten van nieuwe terreinen elders langs de rivier. 
STAHEL ${ }^{1}$ ) heeft gewezen op het feit, dat de oudere grondjes bij de Bosnegers overgaan in een laag secundair bos, door hem genoemd ,,mierenkapoeweri". Inderdaad komt op vele plaatsen waar een dichte bosnegerbevolking gevonden wordt een dergelijke strook secundair bos langs de rivieren voor. Volgens STAHEL ontstaat dit minderwaardig bos door de aanwezigheid van de grote nesten der draagmieren. Volgens zijn berekening kunnen bij een dichtheid van 6 mierennesten per hectare (welk maximum in de omgeving van Paramaribo is geconstateerd maar dat mij naar eigen waarneming in de Bosnegerterreinen te hoog voorkomt) de mieren ieder jaar 2-3 ton bladmateriaal per ha in de grond brengen. Zodoende zou de grond dusdanig met humus verrijkt worden en bovendien door de aanleg van de talrijke nestgangen zoveel extra ventilatie krijgen, dat de zuurgraad en de microbiologische toestand van deze grond zou gaan verschillen van de minerale gronden, waarin het oerbos wortelt. Als bewijs wordt opgegeven ,,dat ook de oudste mieren-kapoeweri vlak achter de dorpen geen neiging vertoont om in normaal hoogbos op te groeien" (p. 13).

Het lijkt mij niet juist, om dit kapoeweri-verschijnsel alleen aan de aanwezigheid en de werkzaamheid van de draagmieren toe te schrijven. Naar mijn mening vormen de mieren hier een lastige bijkomstigheid, want wanneer de oerbosgrondjes door de bevolking verlaten worden en aan de mieren geen nieuw voedselmateriaal meer ter beschikking staat, terwijl de kapoeweri allengs tot hoger bos opgroeit, dan herstelt zich het evenwicht in de mierenpopulatie. Dit proces verloopt in langzaam tempo, afhankelijk van de locale omstandigheden, maar het leidt tot het herstel van de oorspronkelijke toestand. Er is echter één voorwaarde aan verbonden nl. dat het bos lang genoeg achtereen met rust wordt gelaten. Dit laatste nu is in het grondjes-areaal van de Bosnegers niet het geval. Zij komen te vroeg (binnen 10 jaren) terug om weer grondjes te kappen, met het gevolg dat de grond te veel uitgeput raakt en het herstel van het bos onmogelijk wordt.

Een bewijs voor deze zienswijze levert Stahel (1.c.) reeds in zijn beschouwingen over de landbouw van de Bovenlandse Indianen. Het ontbreken van de mieren-kapoeweri aldaar is geen kwestie van een geringere mierenbesmetting zoals STAHEL

1) Het Bosnegervraagstuk en het Coronieplan, Departement Landbouwproefstation Suriname, Mededeling No. 9, October 1944, 28 pp.) 
meent - want die komt plaatselijk even erg voor - maar van een minder intensief gebruik van de bosgronden. De Indianen zijn in klein aantal aanwezig (enkele honderdtallen, tegenover duizendtallen Bosnegers), terwijl slechts gemeenschappelijke grondjes voor één dorp worden aangelegd en niet verschillende voor elk gezin. Bovendien verhuizen de Indianen dikwijls, om nieuwe jacht- en visgronden op te zoeken.

$\mathrm{Er}$ is nog een andere factor die bij het ontstaan van de grondjes-kapoeweri een rol speelt. Dat is het gebruik van vuur bij het openleggen van de grond. Het verbranden van het gekapte bos gaat ten koste van de humus op en in de grond. De bemesting met as die men daarbij krijgt, dekt dit verlies slechts ten dele. Verder ontstaan onder invloed van het vuur grote evenwichtsverstoringen in de microflora en fauna van de grond, waardoor de omzetting van organische stoffen in anorganische verbindingen wordt verhinderd. Zon en regen brengen verandering in de structuur van de geblakerde bodem, die een cementkorst vormt en dichtslaat. Ook onttrekt de teelt van cultuurgewassen, speciaal de cassave, vele minerale bestanddelen aan de grond.

Het is duidelijk dat na deze evenwichtsverstoring, de bodem tijd nodig heeft om zich te herstellen. Deze tijd wordt op 25-30 jaren geschat. De draagmieren spelen daarbij een rol; zij verrijken de grond weer met humus door het aanbrengen van grote hoeveelheden blad in hun grondnesten. Bovendien ventileren zij de grond door het graven van talrijke nestgangen. Op deze wijze dragen de mieren dus bij tot het herstel. Het is trouwens bekend dat de grond op oude draagmierennesten vruchtbaar is; men plant er gaarne bananen op. Wanneer wij met Stahel aannemen dat in deze kapoeweri zes mierennesten per ha gevonden worden, dan zouden deze nesten tezamen slechts een oppervlakte hebben van maximaal 1/10 deel daarvan. Zulks zou nimmer het opgroeien van het bos kunnen belemmeren.

Dat de draagmieren het secundaire bos bezet houden, althans hier in groter aantal aanwezig zijn dan normaal in het oerbos het geval is, kan een gevolg zijn van de aanleg van nieuwe grondjes binnen hun bereik. Door grondgebrek proberen de Bosnegers immers steeds weer om in dit bos grondjes aan te leggen. De mieren kunnen zich bovendien handhaven omdat er verschillende bosbomen zijn, die de mieren voldoende bladmateriaal leveren.

De mierenkapoeweri vormt dus èn door de verminderde bodemcapaciteit èn door de aanwezigheid van de draagmieren, een voor de huidige primitieve Bosneger-landbouw onbruikbaar 
geworden terrein. Ook uit een bosbouwkundig oogpunt is de mierenkapoeweri waardeloos.

\section{HET AGRARISCH RECHT}

$\mathrm{Er}$ is nog een andere omstandigheid die de landbouw van de Bosnegers in de weg staat. Zoals bij vele natuurvolken, speelt ook in het leven van de Djoeka het gewoonterecht een grote rol. Wij hebben reeds gezien, dat per gezin minstens twee grondjes per jaar worden aangelegd. In feite komt het hierop neer, dat zowel de man als de vrouw een eigen grondje bezitten. Nu liggen deze twee grondjes niet naast elkaar of dicht bij elkaar. Integendeel, het ene grondje is doorgaans uren ver van het andere verwijderd; het bevindt zich aan de andere zijde van de rivier of elders langs een boskreek. Men zou kunnen denken dat dit een soort van risicoverdeling is. In werkelijkheid is het een kwestie van familiebezit. Het grondje van de vrouw wordt in het areaal van haar familie gekapt en het grondje van de man in zijn familiecomplex. De grondjes worden dus in groter familieverband aangelegd en niet in gezinsverband. Elke familie heeft een bepaald gebied, waar zij het recht heeft de grondjes te kappen. Dit gebied ligt langs een boskreek, of men legt van de rivier een pad door het bos aan, waarlangs de grondjes worden opengelegd. Niet zelden treden twisten op over het grondgebruik door ,onbevoegden" op bepaald familieterrein.

Een Bosneger kan dus niet zo maar een stuk bos uitzoeken voor zijn grondje, waar het hem goed dunkt. Hij is daarbij gebonden aan het recht van het familiebezit. Dit geldt niet alleen voor de familie onderling, maar in groter verband ook voor de dorpen. Elk dorp heeft zijn areaal, waarbinnen de families uit dat dorp de grondjes aanleggen. Alleen door huwelijk kunnen mannen voor hun vrouwen grondjes aanleggen in het areaal van een ander dorp.

Deze complicaties in de landbouw leiden er toe, dat de landhonger veel eerder optreedt dan anders het geval zou zijn. Er komt nog bij, dat vele Bosnegerdorpen zeer lange tijd, soms 100 jaren achtereen, op dezelfde plaats blijven bestaan. Het is daarom niet te verwonderen, dat mede door de bevolkingsaanwas in zulke centra de limiet van deze roofbouwcultuur is bereikt. De nabije landbouwgronden worden met te kleine rustperioden in gebruik gehouden, met het gevolg dat de grond wordt uitgeboerd en het periodiek herstel van het bos steeds trager verloopt. Bovendien worstelt men in toenemende mate met het probleem 
van de draagmieren, die de gemakkelijk bereikbare plaatsen bezet houden.

Het gevolg van deze omstandigheid is, dat de Bosnegers gedwongen worden steeds verder van hun dorpen de grondjes te maken. Men vaart uren ver de rivier op of af, om bij de goede gronden te komen. Wanneer men geen gebruik kan maken van een boskreek om de producten uit het veld te vervoeren, is men gedwongen om één of twee uren ver de oogst door het bos naar de rivier te dragen. Verder dan twee uren lopen (ca $6 \mathrm{~km}$ van de rivier verwijderd) gaat de Bosneger niet (zie de kaart).

In de Tapanahoni reist men zelfs dagen ver weg, naar minder bevolkte streken, om te planten en te oogsten. Men legt dan z.g. werkkampen langs de rivier aan, vanwaar men in de omtrek opereert. Dit is o.a. het geval tussen Godoholo en Granbori, van mensen uit Drietabbetje of andere centra. Dat men niet nog verder de rivier opgaat, tot voorbij het laatste dorp Granbori, heeft te maken met een verbod van de Granman van de Aucaners. Deze wil nl. de daarboven liggende gronden als jachtterreinen reserveren en dus niet voor landbouw-doeleinden vrij geven.

De bewoners van de dorpen langs de beneden Tapanahoni, zoals van Sajé, Clementi en Malobbi, leggen dikwijls hun kostgrondjes in de Lawa aan, waar zij tot aan de Aboenasoengoe-val over landbouwgronden kunnen beschikken. Verder stroomop in deze rivier, laten de Bonni- of Aloekoe-negers hun rechten gelden.

\section{VERSCHILLEN TUSSEN AUCANERS EN PARAMACANERS}

De hierboven weergegeven toestanden gelden in hoofdzaak voor de Aucaner Bosnegers van de Tapanahoni. Zij tellen heden ongeveer 6500 mensen. De Paramaccaner Bosnegers van de Marowijne, ongeveer 1700 in getal, staan er iets gunstiger voor, omdat zij door hun geringere bevolkingsdichtheid in minder ernstige landnood zijn geraakt. Maar ook hun staat in de naaste toekomst een zelfde lot te wachten. Bovendien weegt in dit gebied het kappen van het bos zwaarder, omdat daarbij exploiteerbaar hout verloren gaat. Aan de Tapanahoni, boven de grotere vallen, is houtkap voorlopig niet mogelijk, zodat het verlies aan hout in deze streken hier nog geen economische rol speelt.

\section{MAATREGELEN TER VERBETERING}

De vraag is nu, of van hogerhand het grondjesbedrijf van de Bosnegers geregeld moet worden. Mijn advies in deze is: Hoe 
eerder hierin verbetering kan worden gebracht, des te beter en wel om de volgende redenen.

le Door het van ouds toegepaste grondjessysteem hebben speciaal de Aucaners van de Tapanahoni thans zulk een grondgebrek, dat een verdere aanwas van de bevolking daardoor gehinderd wordt.

2e De voedselvoorziening van deze Bosnegermaatschappij is precair en eenzijdig; deze dreigt steeds ongunstiger te worden, met als gevolg dat de gezondheidstoestand steeds meer zorg zal vragen.

3e De Bosnegers kunnen niet in staat worden geacht om zelf in deze landbouwmethoden veranderingen ten goede aan te brengen.

$4 \mathrm{e}$ Het bewonen van deze streken wordt voor de jongere generaties steeds minder aantrekkelijk, waardoor een verspreiding van de bevolking over andere gebieden plaats vindt. De mannen trachten werk te vinden in de benedenlanden, of in de bedrijven in Frans Guyana.

5e De houtvoorraden langs de rivieren dreigen door het verkwistende grondgebruik geheel verloren te gaan.

6e Het is te vrezen dat, indien van overheidswege niet tijdig hulp geboden wordt om deze bosbevolking uit de impasse te helpen, de sociale en economische terugslag daarvan spoedig ernstig voelbaar wordt.

De oplossing van dit vraagstuk ligt m.i. hierin, dat in de eerste plaats landbouwmethoden moeten worden toegepast, welke op een beter en economischer gebruik van de grond zijn gebaseerd. Het is de taak van het Departement van Landbouw om te onderzoeken welke mogelijkheden de gronden toelaten en welke gewassen het beste kunnen worden geteeld; het is om deze reden, dat aan deze beschouwingen een lijst van thans bij de Bosnegers in gebruik zijnde gewassen wordt toegevoegd. Door de landbouwvoorlichtingsdienst zal een kleine ploeg van jonge Bosnegers in opleiding moeten worden genomen, teneinde hen vertrouwd te maken met de nieuwe methoden.

Daarnaast zal de mierenbestrijding ernstig ter hand genomen moeten worden, in overeenstemming met de plannen voor een gewijzigde landbouw. Ook hiervoor zullen mensen uit de eigen omgeving een opleiding moeten ontvangen, en een permanente werkploeg gevormd worden. Het is ondoenlijk en ook niet nodig om het gehele thans in gebruik zijnde areaal te gaan zuiveren. Insecticiden zoals zwavelkoolstof, methylbromide en parathion - mits met de nodige voorzichtigheid toegepast - zullen echter plaatselijk met succes kunnen worden gebruikt. 
Ook zal het Districtsbestuur medewerking moeten verlenen om een compromis te vinden tussen de gewoonterechten van de Bosnegers en de nieuw in te voeren regelingen over het grondgebruik.

\section{DE CULTUURGEWASSEN EN HUN GEBRUIK}

Hoewel het voor het merendeel cultuurplanten betreft die in Suriname algemeen als landbouwgewassen in gebruik zijn, is in detail toch niet veel bekend van de gewassen welke door de Bosnegers voor hun onderhoud worden verbouwd. Het geven van een overzicht van deze planten is dus in de eerste plaats nodig, met vermelding op welke wijze zij worden gebruikt.

Uit een meer historisch oogpunt is het van belang te wijzen op enkele importplanten, die uit Afrika afkomstig zijn en alleen nog bij de Bosnegers in gebruik zijn gebleven, zoals agobo en bongila. Verder zijn hier vermoedelijk nog variëteiten van gewone cultuurplanten aanwezig - zoals: suikerriet, bacove en bananen, tajeren yams-soorten, - uit de tijd, dat de weggelopen slaven deze van de toen bestaande plantages medenamen.

In verschillend opzicht loont het dus om na te gaan wat er geteeld wordt. De navolgende opsomming is samengesteld uit gegevens van eigen waarnemingen en uit inlichtingen die door verschillende Bosnegers zijn verstrekt. Deze lijst is niet volledig; het ontbrekende is echter waarschijnlijk van ondergeschikt belang.

\section{A. CULTUURGEWASSEN DIE OP DE KOSTGRONDEN GETEELD WORDEN}

\section{Bittere cassave (kasàba).}

Dit is het voornaamste gewas, waarvan het cassavebrood en de kwak wordt gemaakt. Men plant de stekken in December, maar ook in Maart en April. Na 12 maanden begint de oogst; bij voedselgebrek wordt na 7 maanden reeds gerooid. Men onderscheidt gele en witte variëteiten, naar de kleur van het inwendige der knollen. Tot de gele variëteiten behoren: witti tiki die tot twee jaren op de grondjes wordt aangehouden, blaka tiki die maar een jaar op de grondjes staat, en taja tiki die ook lange tijd product levert en vooral goed is voor het maken van kwak. Tot de witte variëteiten behoren: amosiang, sanang kasaba en domberi. Hiervan bereidt men het cassavebrood. Bij het maken van kwak mengt men alle kleuren door elkaar om de gewenste gele kleur te krijgen. Elke variëteit apart levert een minder smakelijk product.

Aan de Marowijne maakt men meer kwak (kwaka) dan cassavebrood, terwijl aan de Suriname rivier en de Saramacca alleen cassavebrood 


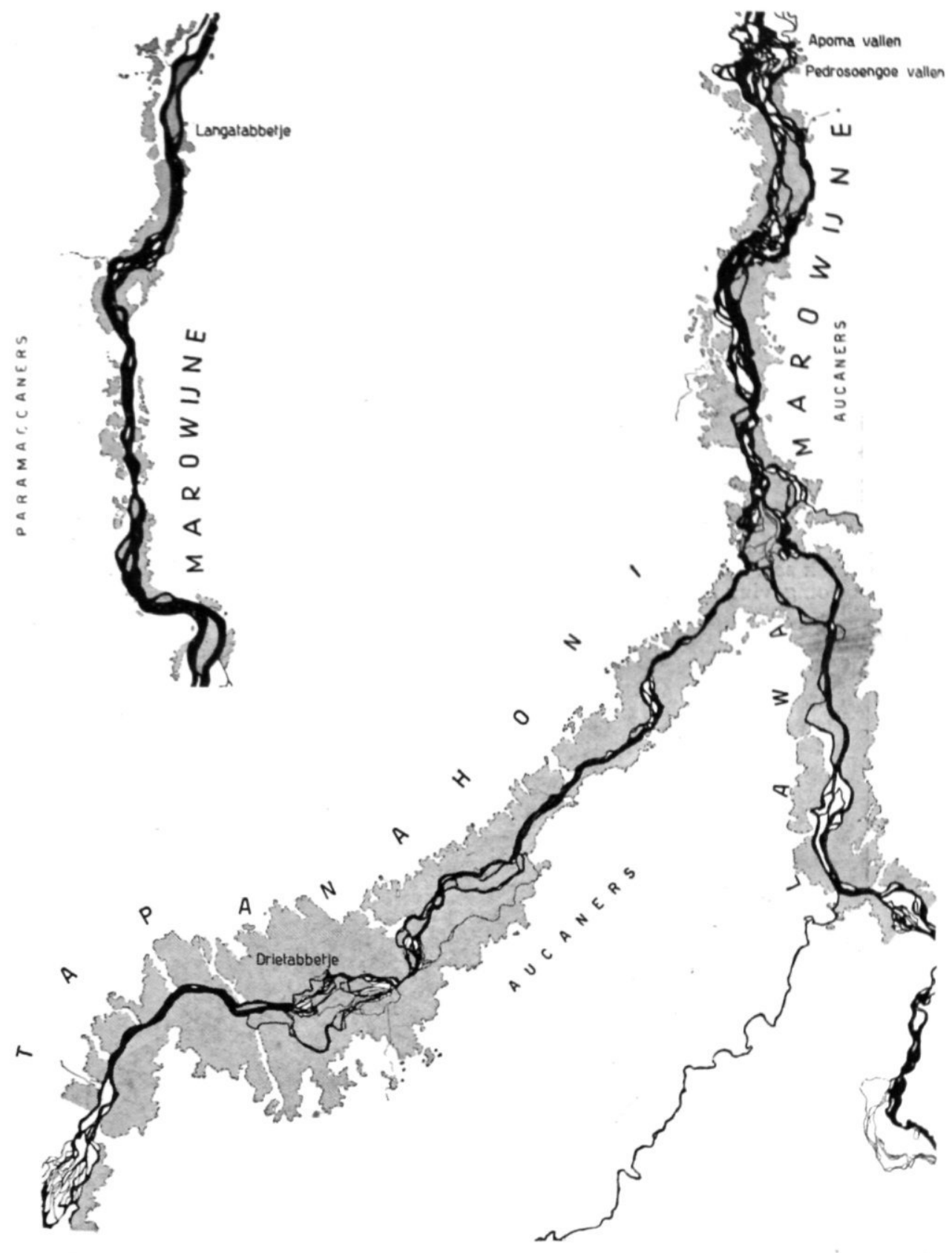

Overzichtskaart van de landbouwgronden van de Bosnegers van de Marowijne. Vervaardigd naar luchtfoto's door het Centraal Bureau Luchtkaartering Paramaribo. Opgenomen in 1947. 


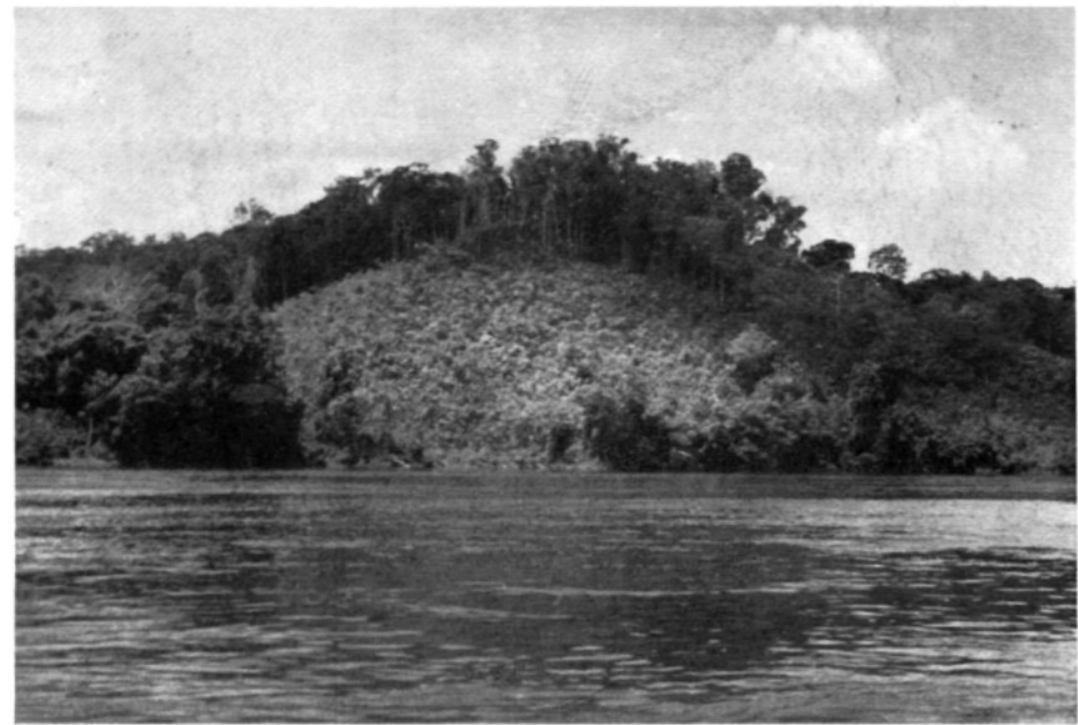

Fig. 1. Grondje van een Paramaccaner op een heuvel langs de rivier. Bij gebrek aan vlakke terreinen worden de hellingen van de heuvels benut. De omgeving is secundair bos. - Marowijne bij Grankreek, Oct. 1952.

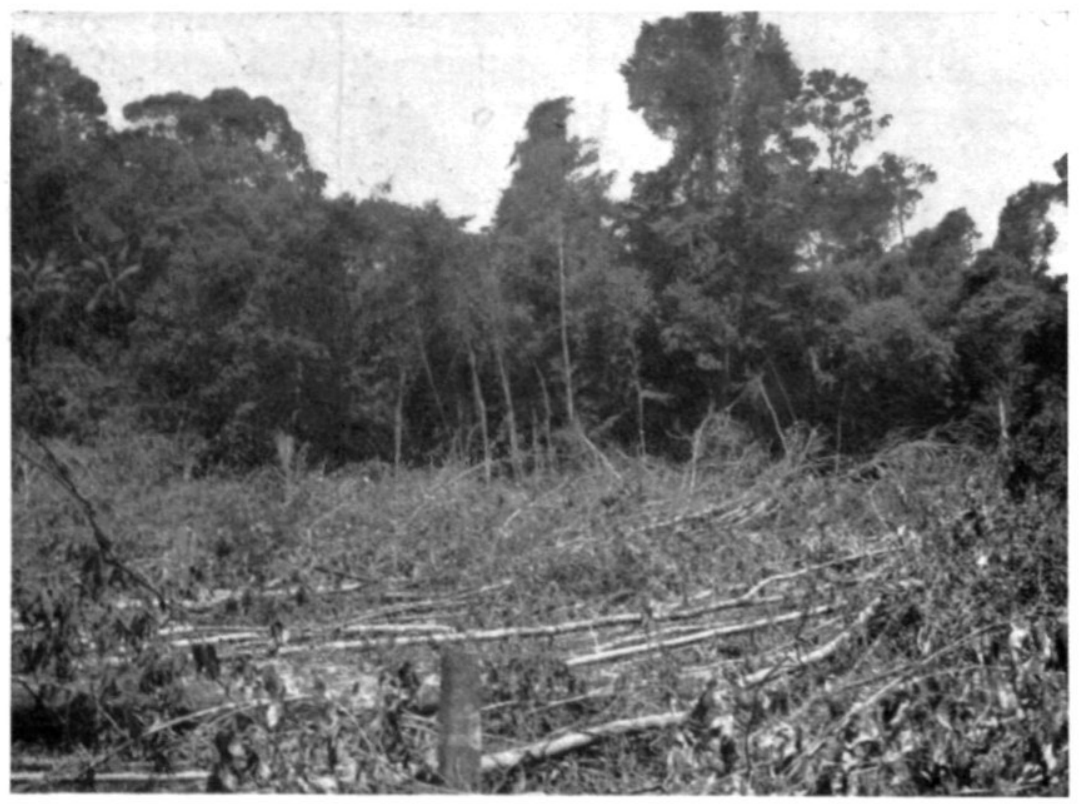

Fig. 2. Nieuw aangelegd grondje van een Aucaner, in jong secundair bos. De dunne stammen zijn typerend. - Tapanahoni, Saniki, Oct. 1952. 


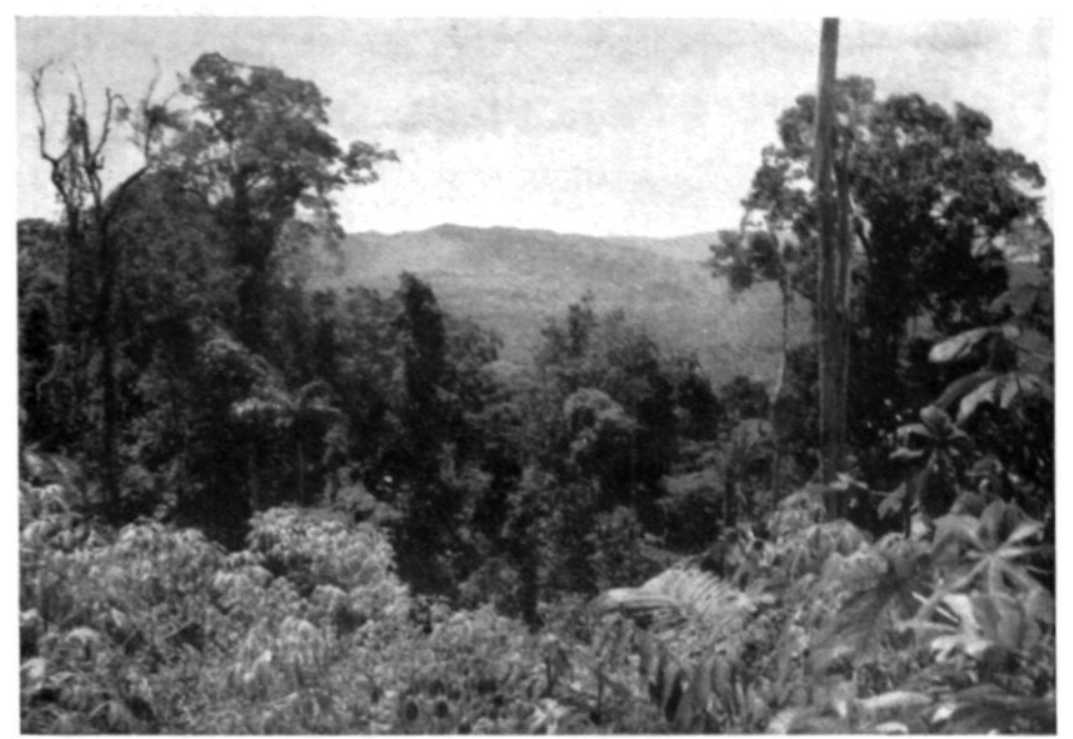

Fig. 3. Grondje op de hellingen van het Malobbi-gebergte. De omgeving is primair oerwoud; in de verte het Lely-gebergte. - Tapanahoni, Malobbi Oct. 1952.

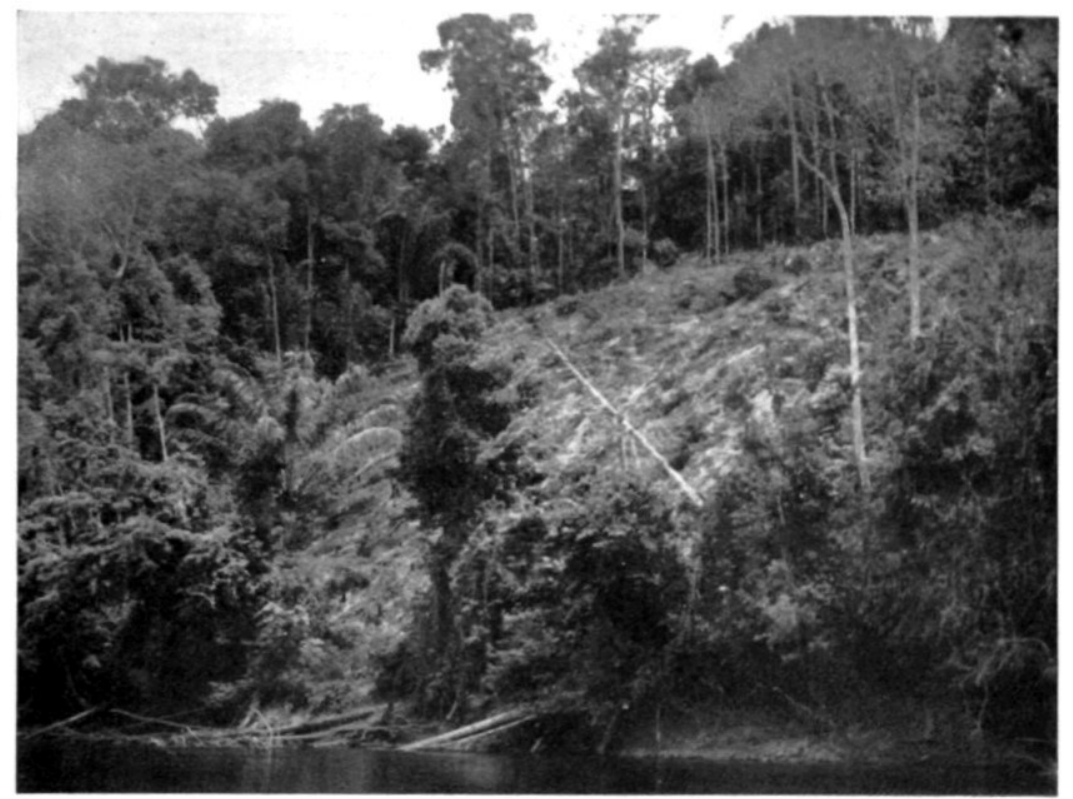

Fig. 4. Vers gekapt grondje langs de rivier, op een steile helling. Het gevaar voor erosie is groot. De omgeving is secundair bos. - Marowijne bij Grankreek, Oct. 1952. 


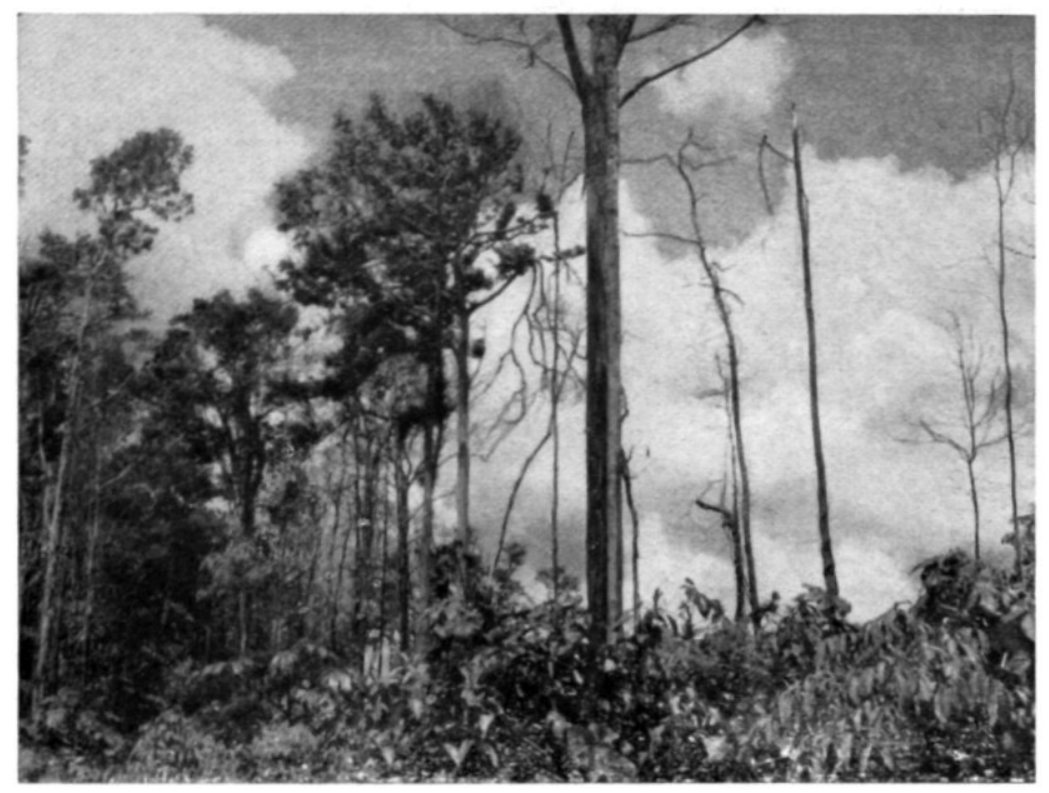

Fig. 5. Oerwoud in het Malobbi-gebergte, met ernstige brandsporen van een kostgrondje (op de voorgrond). - Tapanahoni, Malobbi, Oct. 1952.

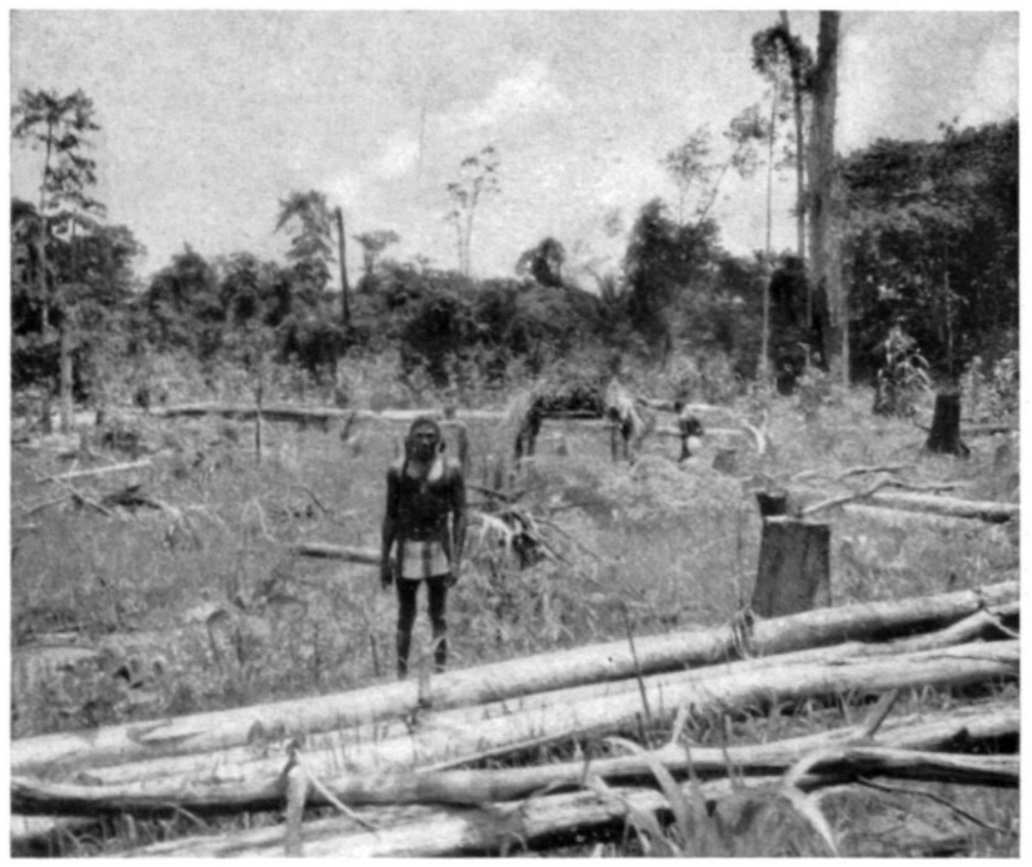

Fig. 6. Kostgrondje op rivierterras, gedurende drie maanden beplant. Op de voorgrond rijst en cassave, daarachter mais. De omgeving is kapoeweri en, rechts, hoger secundair bos. - Tapanahoni, Drietabbetje, Maart 1952. 


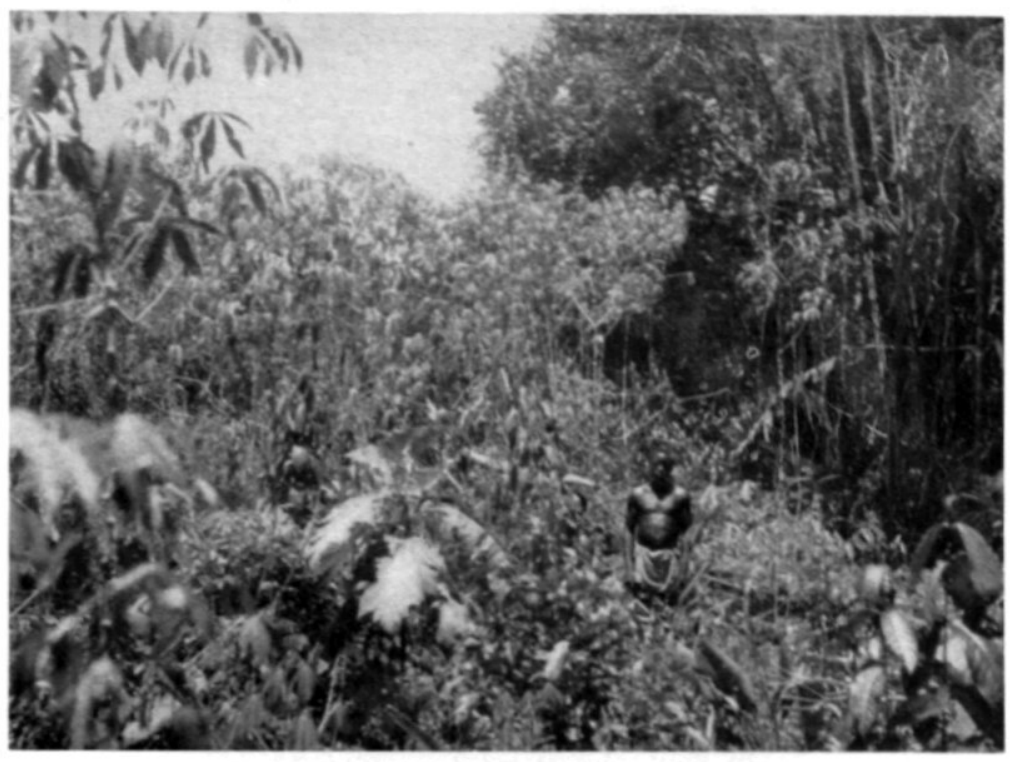

Fig. 7. Tien maanden oud kostgrondje met hoge cassave. Rechts kapoeweri; de voorgrond met onkruiden. - Tapanahoni, Drietabbetje, Oct. 1952.

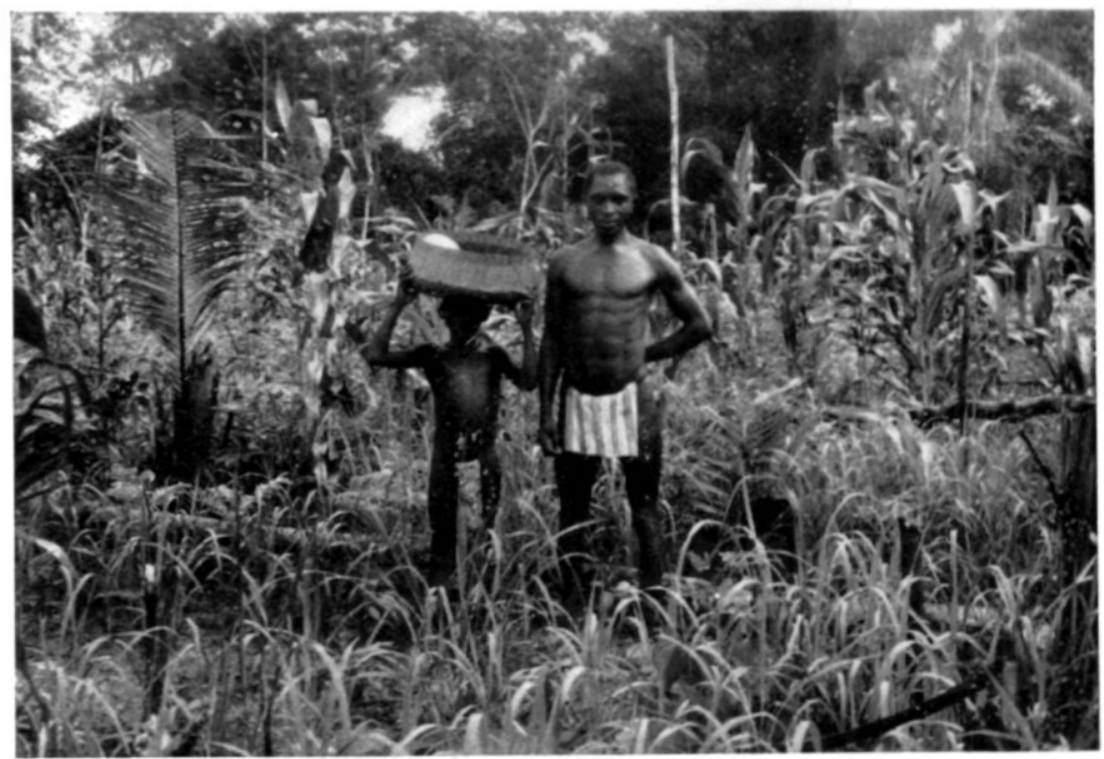

Fig. 8. Ruim drie maanden oud kostgrondje met oogstbare mais en watermeloen. Op de voorgrond rijst. - Tapanahoni, Drietabbetje, Maart 1952. 


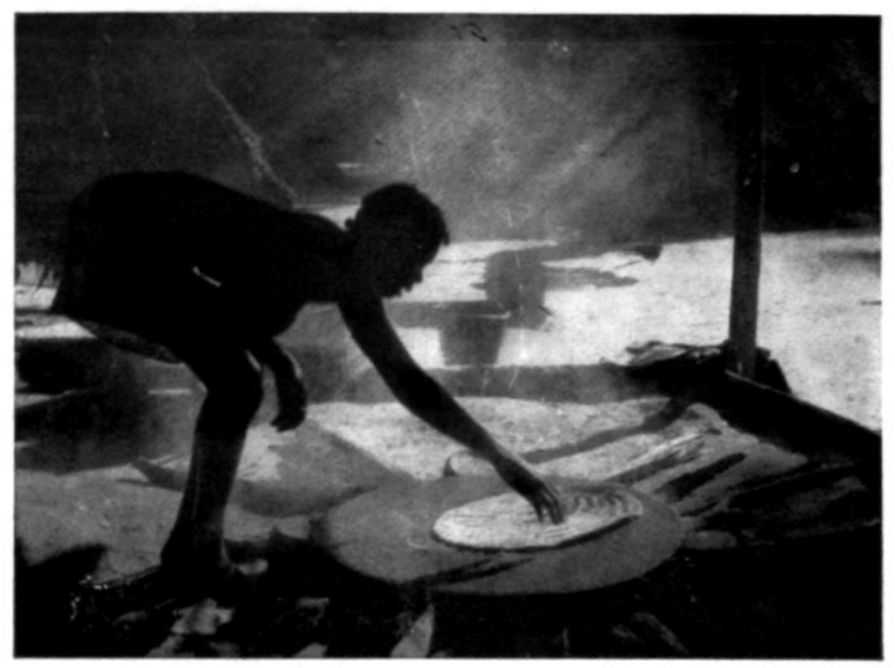

Fig. 9. Het bakken van cassavebrood op de ijzeren bakplaat (de ,,pan”). Tapanahoni, Drietabbetje, Juni 1952.

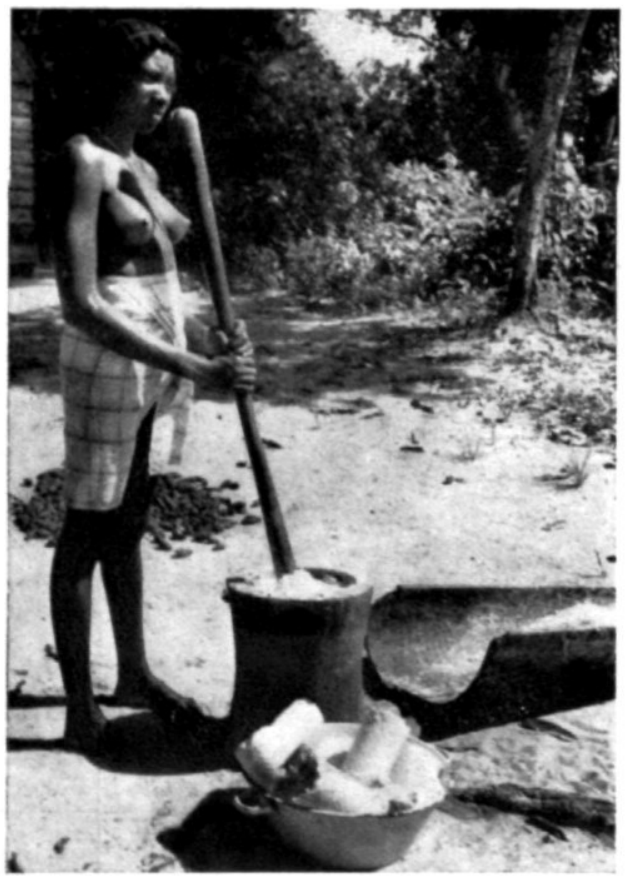

Fig. 10. Het stampen van uitgeperste cassavebrokken (in de bak op de voorgrond) in een houten vijzel (de ,,matta") tot meel, om brood van te bakken. - Marowijne, Albina, Apr. 1953. 


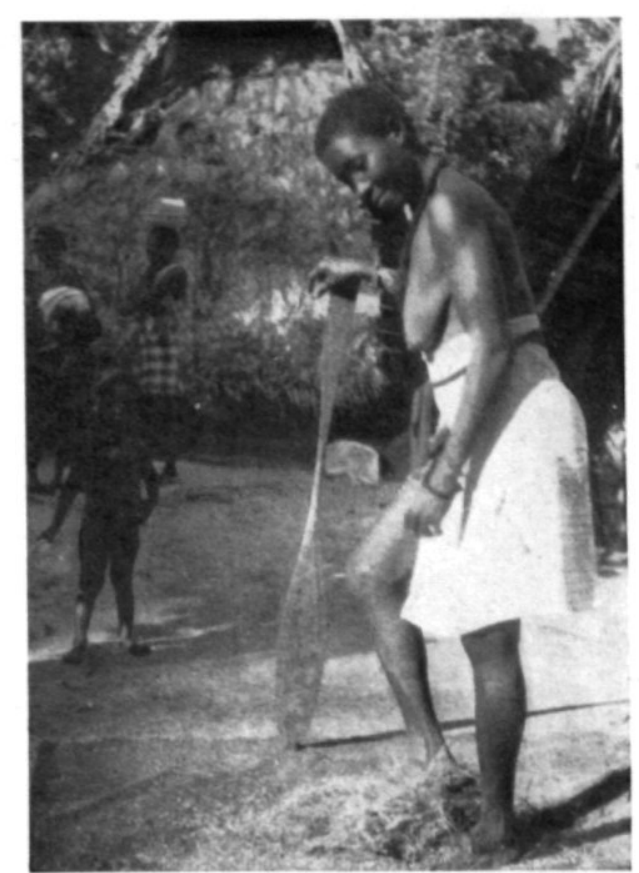

Fig. 11. He dorsen van rijstaren met de voeten, op een zak. - Tapanahoni, Drietabbetje, Juni 1952.

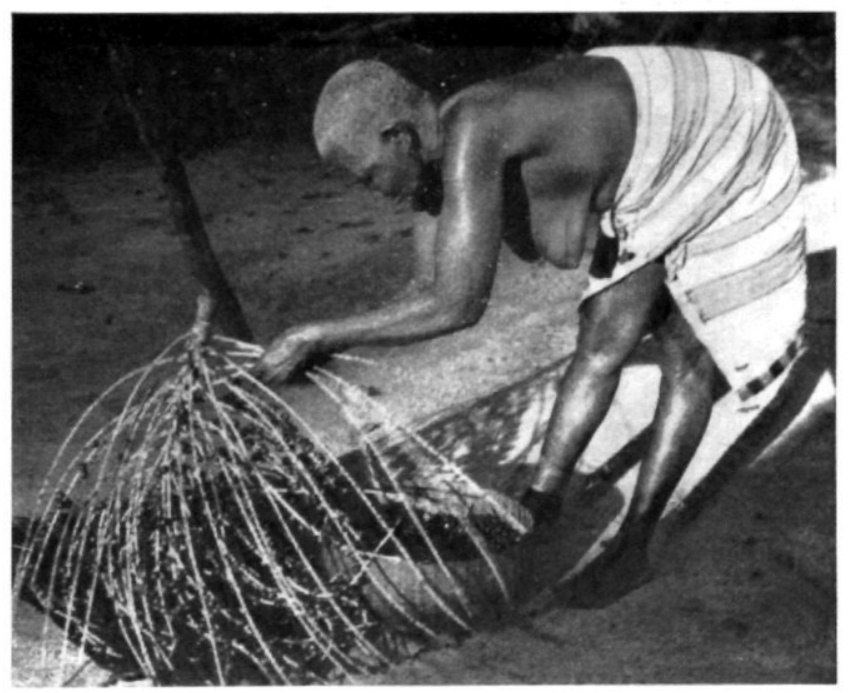

Fig. 12. De vruchten van de pina-palm worden in een mand verzameld; van het vruchtvlees wordt een drank bereid. - Marowijne, Albina, Apr. 1953. 


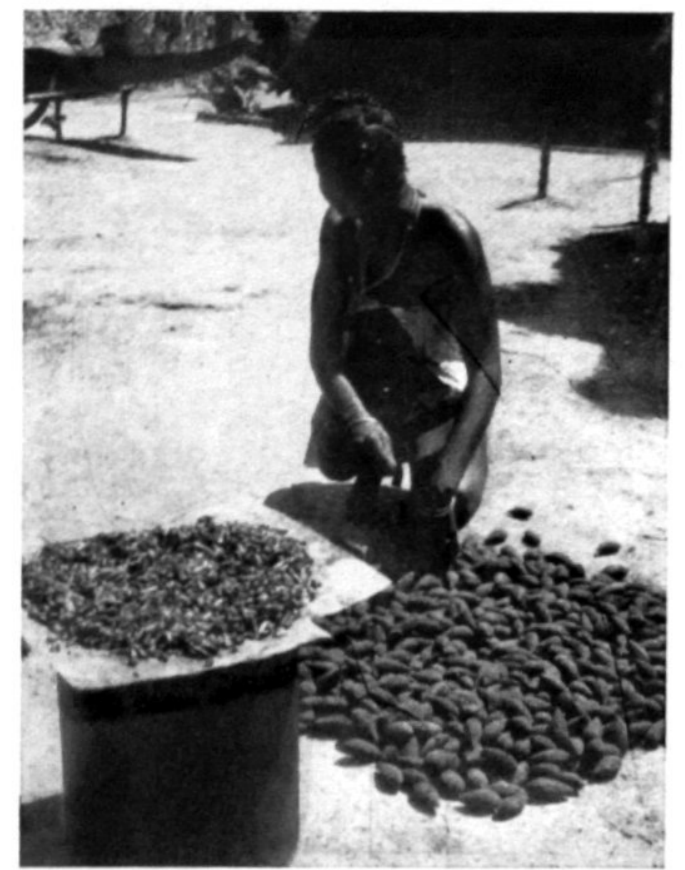

Fig. 13. Het pitten van de maripa-palm, waarvan de kernen (liggend op een plaat op een kerosine. blik), na droging in de zon, worden gebruikt om er spijsolie uit te koken. - Tapanahoni, Drietabbetje, Juni 1952.

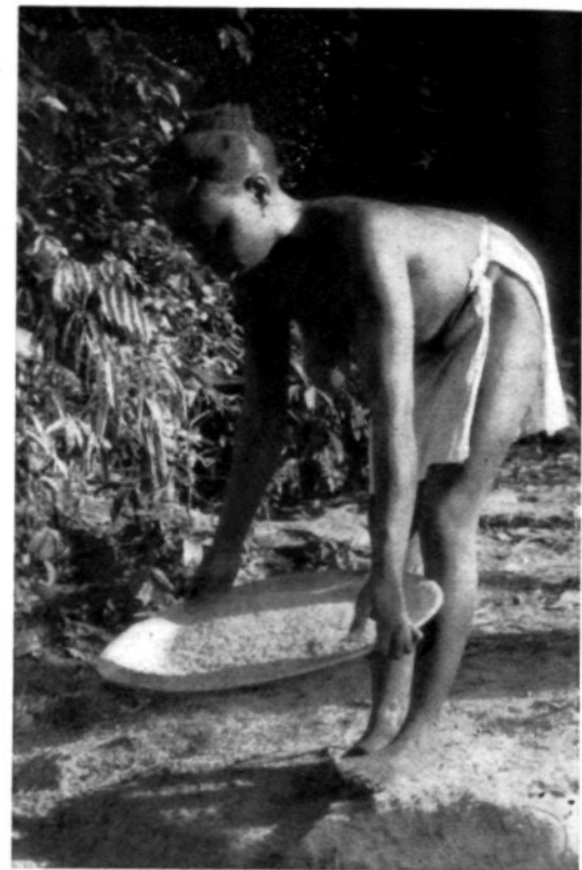

Fig. 14. Het wannen van rijst met de ",kède", nadat deze in een matta is gestampt. - Tapanahoni, Granbori, Mei 1952. 
van het meel gebakken wordt. Kwak wordt op de volgende wijze bereid: de knollen worden, na geschild te zijn, twee dagen lang in water in een korjaal ${ }^{1}$ ) gelegd en dan geraspt. Deze geraspte cassave laat men verzuren in een kist of een korjaal; daarna wordt het raspsel uitgeperst met de matapi ${ }^{2}$ ) en vervolgens op de bakplaat (pan) gebakken, waarbij de korrelige massa steeds omgeroerd wordt. De kwak bestaat uiteindelijk uit droge gele korrels. Kwak kan men langer goed houden dan broden. Het wordt met water opgeweekt en met wat suiker (indien aanwezig) gegeten.

Een minder gebruikt product is ,,afringi”. Hiervoor raspt men vers geschilde cassave, perst het raspsel daarna uit in de matapi en droogt het meel op vuur of in de zon. Vervolgens stampt men dit meel in de matta ${ }^{3}$ ), en kneedt het daarna met water tot balletjes. Deze worden tezamen met vis of vlees tot een soep gekookt. Men noemt deze soep ,,afringi", dat letterlijk gooien betekent, vermoedelijk omdat men de balletjes in de pot gooit. Hetzelfde product noemt men aan de Suriname-rivier , apitie".

Zoete cassave (kasàba-swieti) wordt weinig geplant; de knollen worden na drie maanden geoogst en gekookt gegeten.

De voornaamste plagen in de cassave zijn: draagmieren die de bladeren afknippen, herten die de jonge toppen wegvreten en ook de stengels afbijten, tapirs die stengels en bladeren vreten, en ook veel vertrappen, koni-koni's 4) die de knollen uitgraven en afknabbelen, pingo's en pakiera's $^{5}$ ) die de knollen uit de grond wroeten en opvreten.

Rijst (alésie).

Naast cassave is rijst een belangrijk hulpgewas. Men zaait de rijst breed uit met de hand tussen de andere gewassen en tjapt ${ }^{6}$ ) het zaad licht onder. De zaaitijd valt in December tot Februari of Maart. In de vierde maand is de rijst rijp. De oogsttijd valt daardoor in de grote regentijd van Mei tot Juli (aan de Suriname-rivier iets later). Alleen de aren worden afgesneden en deze worden in de zon gedroogd op de grondjes of in de dorpen. Men teelt alleen droogland-rijst in talrijke variëteiten, zoals :

kasiwini, de beste soort met lange witte korrels;

ajengena, met korte fijne korrel, geeft bij stampen een mooie witte rijst; abalahede, met platte ronde korrel;

witti-alesie of paramakka-alesie, in de aar licht gekleurd;

lebi (redi) - alesie, als padi geel, groeit ook op zwampige plekken;

aloeloe of loeloe, legert vlug, heeft een goede korrel;

pindé-alesie, korrel van buiten gespikkeld;

asinkini, variëteit met lange korrel, wordt veel aangeplant

1) korjaal $=$ boot

$\left.{ }^{2}\right)$ matapi = lange koker van vlechtwerk waarmede men uit de ge-

raspte cassave het sap en het water perst.

3) matta $=$ grote houten vijzel

4) koni-koni $=$ Surinaams konijn

5) pingo en pakiera $=$ bosvarkens

6) tjappen $=$ het loswerken van de grond met een hak.

West-Indische Gids XXXV 
Andere variëteiten zijn nog: rexora, saka, mabosoe, mooidd, sika-sirie, bakaté-saka, dendelei, mooimasra, wittifang, skati, blakatère, mesiti, pikienloeloe, trampoeloekoe.

De Bosnegers bewaren de rijst in de aren en dorsen de padi met de voeten door er over te lopen, nadat ze gedroogd is op zinkplaten of op zakken. De padi wordt in de matta gestampt wanneer men een maal nodig heeft. Men eet dus ongeslepen zilvervlies-rijst en deze wordt op de gewone wijze met vlees of met vis tegelijk gekookt. Bij een goede oogst heeft men het hele jaar door rijst, tot de volgende oogst, maar dikwijls is de hoeveelheid slechts voor enkele maanden toereikend. Bij gebrek koopt men ook geslepen rijst uit de winkels langs de Marowijne.

Bij het uitzaaien ondervindt men veel last van ,,stondoifie's "') die het zaad opvreten; de rijpende aren worden geplunderd door een zwarte vogelsoort ,,andokie", korenparkieten of pikoetoes en het rijstvogeltje ",tie". Het verlies dat door deze vogels geleden wordt is dikwijls aanzienlijk. Andere plagen in de rijst zijn niet verder bekend, of genoemd.

\section{Bananen (bána).}

Deze worden steeds geplant, maar in verhouding tot cassave minder veelvuldig. De plantsoenen zet men gewoonlijk wat later in de grond dan de cassavestekken, om ze gelijk te laten opgroeien. Het komt ook voor, dat een bepaald stuk van een grondje alleen met bananen en bacoven beplant wordt, omdat deze anders de overige gewassen met hun schaduw te veel hinderen. Na 10-15 maanden zijn de bossen rijp.

Er zijn verschillende variëteiten in gebruik:

granbána, 5 maanden na het uitstoten van de bos rijp; vruchten lang; oemanbána, 3 maanden na het uitstoten van de bos rijp; vruchten lang; patamacca-bána, idem; vrucht kort en wat zuur van smaak;

doengoe, idem; vruchten lang, dikwijls met tweelingvingers; kodjakondre, idem; vruchten kort.

De bananen worden als ,groene bananen" gekookt, of als rijpe bananen eerst gekookt en dan fijn gestampt tot ,,tomtom". Ook worden rijpe banen rauw gestampt, dan met cassavemeel gemengd en tot ,,koekoe" gebakken.

Bacoven (bakóeba, bákba).

Plantwijze als bij de bananen. De groeitijd wisselt van 10 tot 15 maanden. Het meest wordt de bananen-bacove geteeld. De soorten worden met de volgende benamingen aangeduid:

bigibakoeba of langa-finga, bananen-bacove met lange vruchten (Gros

Michel type); stoot na 10 maanden de bos uit en deze rijpt na 5 maanden; watramama-bakoeba, een soort congo-bacove, afkomstig uit Frans Guyana, korte soort; bos rijpt na 3 maanden;

koboto-bakoeba of soekroe-finga, kleine gele zoete soort ter grootte van de appelbacove of kleiner (missie-finga); bos rijpt in 3 maanden;

indji-bakoeba, korte dikke rode soort, zoet van smaak met geel vruchtvlees; bos rijpt in 3 maanden.

De bacoven worden alleen als verse vrucht gegeten en zijn zeer gewild.

$\left.{ }^{1}\right)$ stondoifies = kleine duiven, letterlijk steenduiven. 
De bladeren van bananen en bacoven worden soms in sterke mate door draagmieren afgevreten.

Tajer (tája).

Op alle grondjes vindt men tajer in groepjes verspreid staan. $\mathrm{Na}$ 8-10 maanden wordt geoogst (Augustus-October) maar ook doorlopend daarna. Er zijn verschillende soorten in gebruik:

agauw, grote soort (pomtaja); knollen blijven lang goed; komt ook op de dorpen voor;

sjoe, kleinere soort met geelachtige knol, knollen blijven lang goed; het blad wordt als groente gegeten;

dasini, grotere soort met geelachtige knollen welke wegens zijn smakelijkheid veel geplant wordt; het oogsten gebeurt bij kleine beetjes tegelijk, want de knollen rotten vrij gauw; ook hiervan wordt het blad als groente gebruikt; een kleine soort dasini wordt ook wel chinees taja genoemd;

wititaja, kleinere soort; knollen blijven lang goed; blad wordt ook gegeten.

Tajerknollen worden als aardappel, dikwijls met vis of vlees en olie, tot een soep gekookt.

Pataten (patáta).

Pataten worden pleksgewijs geplant; ze kruipen als onkruid met lange ranken tussen alles door. Ook nadat de grondjes verlaten zijn, blijven ze op de open plekken doorgroeien. Ze worden in de grote droge tijd geoogst, maar men heeft ook driemaandse soorten. Er zijn witte, rode en gele soorten onder de volgende namen:

plata patata, witte soort, veel aangeplant;

lebi (redi) patata, rode soort, veelal verwilderd;

abawini, gele soort, veelvuldig op grondjes aangeplant;

sakoela patata, gele soort, idem.

De knollen worden gekookt gegeten als aardappelen, meestal met olie toebereid, of in kleine stukken gesneden tot soep verwerkt. Konijnen en varkens zijn eveneens liefhebbers van deze knollen.

Napi (napi).

Men plant de napi's verspreid naast stokken, om de ranken te laten opklimmen. Ze ontbreken op geen enkel grondje. De oogsttijd valt in de grote drogetijd van September tot November. Men kent rode en witte soorten, die onder de volgende benamingen bekend zijn:

kakaboeroe, rood van binnen, met rode schil; gangasombo, wit van binnen, met rode schil; witti napi, wit van binnen, met gele schil;

finga napi, paarsrode soort met verdeelde knollen;

waka waka-napi, paarsrode soort, kruipend, met grote, lange knollen.

Napi wordt gekookt gegeten als aardappel. De meeste soorten worden ongeschild gebruikt; wanneer ze tezamen met vlees worden bereid ontdoet men echter de knollen van de schil. 
Yams (yamesi)

De yams komt algemeen voor en wordt verspreid aangeplant. De oogsttijd is October of later. Men kent twee soorten:

maka yamesi, met doorns aan stengel, geplant met knoppen van knollen; afakóh, geplant met stengelstekken.

Yamswortels worden dikwijls zeer groot. Men kapt ze in stukken en kookt de brokken zoals tajerknollen.

Mais (kaloe).

Mais wordt tezamen met andere gewassen gezaaid en levert een van de eerste producten; het oogsten geschiedt na drie maanden (Maart). Men kent slechts één soort. Soms legt men speciale maispercelen aan (Paramaccaners).

Men eet de jonge mais gekookt of geroosterd, soms ook gestampt en tot korenpap (kaloepapa) gekookt. Een bekende lekkernij is ,,ansowé" of ,,asogrie", gemaakt van fijn gestampte geroosterde droge korrels, vermengd met suiker.

Watermeloen (watramoen).

Deze wordt overal pleksgewijs op de grondjes aangeplant; de oogsttijd valt in Maart. Er zijn twee soorten in gebruik:

hesiskin en blakaskin, welke beide kleine ovaal-ronde witgevlekte vruchten leveren, met een flauw-zoet lichtroze vruchtvlees; de vruchten worden vers gegeten.

\section{Pompoen (pampoen).}

Deze plant vindt men op vele plaatsen, maar nooit talrijk.

Men kent slechts de langwerpige donkergroene soort; de oogsttijd is van April af, en lange tijd daarna. De vruchten worden, in stukken gesneden, gekookt gegeten.

\section{Oker (okrò).}

Dit gewas wordt algemeen op de kostgrondjes geteeld; het levert, na drie maanden, in Februari en Maart eetbare vruchten. Men onderscheidt drie soorten:

sebiwiki, met korte vruchten;

afoesibobi, met korte vruchten;

diatoetoe, met lange vruchten.

De jonge groene vruchten worden in stukken gesneden en tot een soep gekookt, meestal tezamen met tajer, vlees enz.

Pinda (pienda) en Djoekapinda (agobo).

Beiden worden pleksgewijs op de grondjes en niet zelden ook in de dorpen aangeplant; zij bloeien in Maart en worden na de rijst geoogst, in Juni en Juli. De hoeveelheden die geoogst worden zijn gering en bedragen per man een of twee kerosine-blikken vol. Zowel van de gewone pinda als van de djoekapinda is maar één soort bekend.

Men kookt de pinda tot soep of men maakt er pindakaas van, door ze te roosteren en dan te stampen in de matta. De Saramaccaners noemen de djoekapinda ,,gobogobo". 
Bongila.

Deze is verwant met abongra (Sesamum) met witte bloemen en met platte witte zaden in lange zaaddozen. $\mathrm{Zij}$ wordt vrij veel tussen andere planten breeduit gezaaid en de stengels met de zaaddozen worden in Juni geoogst. Er is maar één soort van bekend.

De rijpe zaadjes, plat en wit, worden na voorgedroogd te zijn in een pan op het vuur, gestampt in een matta. Men voegt daarna wat zout toe en gebruikt dit product als pindakaas op cassavebrood. Het is smakelijk en voedzaam. Aan de Suriname rivier noemt men deze plant , waja" en de zaadjes bakt men met het cassavemeel mee in het brood. Evenals abongra, is vermoedelijk ook deze plant van Afrika afkomstig.

\section{Bonen (pesi).}

Deze zijn heel weinig in gebruik. Men kent kousebandjes - klimbonen met lange, dunne peulen - en een soort met witte bloemen welke $20 \mathrm{~cm}$ lange peulen maakt. Andere bonen-soorten worden niet geteeld, ofschoon de Bosnegers zeer gaarne pesi-soorten eten.

\section{Suikerriet (keeng of sigáloe).}

Dit ontbreekt nergens en wordt behalve op de grondjes, ook in de dorpen aangeplant. Het blijft met bananen nog jaren op de verlaten grondjes staan en wordt daar ook gesneden. Men onderscheidt drie soorten:

abaiboesi, rood en zwart getekende stengels; alleen vers gegeten;

pikien keeng, kleine soort met dunne stengels; wordt niet met de houwer gekapt, maar met de hand afgebroken; men maakt er obia ${ }^{1}$ ) van; switi-keeng, de gewone soort, die het meest wordt gebruikt: de stengels worden vers gegeten (gekauwd) of het sap wordt met de houten suikerpers (ma) uitgeperst en ingekookt tot een stroop (lika), die in koffie of in awarra-stampsel ${ }^{2}$ ) genuttigd wordt.

$\mathrm{Bij}$ feesten kapt men de stengels in stukken en laat deze in water in een korte korjaal (komata) uittrekken. Dit water wordt later in een pot verwarmd en tot een alcoholische drank (djojo) gegist.

\section{Ananas (nanási).}

Deze wordt geregeld geteeld waarbij de stekken op de grondjes verspreid staan; na één jaar leveren de planten vruchten. Men onderscheidt twee soorten:

bigi nanasi, een witte soort;

indji nanasi, eveneens een witte soort, maar zoeter.

De vruchten worden vers gegeten. Met suikerriet en bananen groeien ananassen nog lang op de oude grondjes.

\section{Papaja (papái).}

Er staan weinig papaja's op de grondjes, maar vele langs de randen van de dorpen, waar ze tot lange, hoge bomen uitgroeien.

Een lange rode soort noemt men bobi papai, een korte gele soort papai. De vruchten worden vers gegeten, soms ook groen gekookt.

1) obia $=$ geestesgeneesmiddel.

$\left.{ }^{2}\right)$ awarra = stekelpalm welke eetbare vruchten levert. 
Tabak (tabáka).

Op verschillende plaatsen wordt op bescheiden schaal tabak aangeplant. De bladeren zijn na 4-5 maanden. (April-Mei) plukrijp; de manshoge plant bloeit na 7 maanden met kleine, roze bloemen.

$\mathrm{Er}_{\mathrm{r}}$ is maar één soort tabak in gebruik, vermoedelijk dezelfde die door de Bovenlandse Indianen wordt geteeld. De bladeren worden in de woonhutten aan de zolder te drogen gehangen. Bij gebruik worden de gedroogde bladeren in een klein blikje met water geweekt en het sap dat in de handpalm wordt gegoten, opgesnoven en weer uitgesnoten.

\section{Bóembie.}

Dit is Tephrosia toxicaria, waarvan de wortels als visvergif worden gebruikt. De manshoge planten vindt men verspreid op de grondjes staan, waar ze worden uitgezaaid tegelijk met de andere gewassen. De plant heeft behaarde bladeren en bloeit met roze bloemen in trossen.

Men gebruikt de gedroogde wortels om er in de droge tijd bij lage rivierstand tussen stenen mee te „ponzen”. Deze bewerking bestaat uit het tot vezels fijnkloppen van de wortels, waarbij het vergif als een melkachtige substantie vrij komt en zich in het water verspreidt. Op deze wijze worden vooral warawara's - op anders moeilijk bereikbare plaatsen - buitgemaakt. Volgens de Bosnegers werkt boembie beter dan nekoe ${ }^{1}$ ).

\section{B. VRUChTBOMEN, STRUiKen EN OVERBLIJVENDE PLANTEN DiE IN DE BOSNEGERDORPEN GEVONDEN WORDEN}

Behalve de tijdelijke gewassen, die op de grondjes geteeld worden, benut de Bosneger ook vruchtbomen en andere meerjarige gewassen, die in en langs de rand van de dorpen geplant worden. De meeste behoren tot de welbekende import-planten; enkele palmsoorten zijn inheems. Wellicht waren deze laatste reeds bij de aanleg van het dorp ter plaatse aanwezig of zijn zij door het gebruik van de pitten min of meer toevallig daar opgegroeid. De volgende soorten zijn genoteerd.

\section{Cocos (kokonòto).}

Komt vrijwel overal in de oudere dorpen voor, maar staat gewoonlijk schraal door het steeds aanvegen van de grond; op gunstiger plekken groeit deze redelijk goed. De productie is matig. De noten worden vers gegeten of als waternoten leeggedronken. Vele stammen vertonen de sporen van Castnia daedalus-aantasting (Drietabbetje, Fisiti, Granbori).

Manja (majang).

Groeit op alle dorpen tot machtige bomen uit en levert in FebruariMaart vruchten, die vooral door de jeugd gaarne worden gegeten. Tetémanje en roodborstje zijn de meest voorkomende soorten. Verlaten dorpen langs de rivieren zijn dikwijls nog door de manjabomen getypeerd.

Citrus.

Is vertegenwoordigd door lemmetje (lemmeki), zure oranje (alanja),

1) Nekoe $=$ een liaan (Lonchocarpus) die ook als visvergif wordt gebruikt. 
sinaasappel (pesina) en citroen (soetoen). Deze volgorde drukt ongeveer de relatieve frequentie uit. Ze komen verspreid voor en groeien, ondanks de verwaarlozing, opvallend goed. Met weinig moeite zou de aanplant van sinaasappels uitgebreid kunnen worden. Lemmetjes en zure oranjes worden veelal gebruikt om vlees en diverse voorwerpen mee te wassen.

Gujave (gobai).

Staat verspreid en ontbreekt nergens; de vruchten worden vooral door de jeugd gegeten.

Zuurzak (atoekoe).

Komt hier en daar voor; de vruchten worden vers gegeten.

Broodboom (belebong, brèdebong).

Is in vele dorpen te vinden. Het is meestal de kastanje-broodvrucht waarvan alleen de pitten gegeten worden, geroosterd of gekookt. In Langatabbetje zagen wij ook de gewone broodvrucht.

Koesoewé (koesoewé).

Staat in elk dorp, maar komt minder voor dan bij de Indianen. De grote roze bloemen en de rode vruchten dragen veel bij tot verfraaiïng van het dorp. De Bosnegers gebruiken de rode kleurstof van de zaadjes om de honden mee in te smeren tegen ongedierte.

Katoen (katoen).

Ziet men op verschillende plaatsen langs de randen van de dorpen en tussen de woonhutten staan. De katoen zelf wordt bij uitzondering door de vrouwen gebruikt om te spinnen. Van de katoendraad maakt men kuitbanden (sepoe) naar Indiaans model en soms ook hangmatten.

\section{Koffie.}

Wordt hier en daar in het bos langs de rand van het dorp gevonden (Drietabbetje, Poeketti). Het is de kleine soort, vermoedelijk Coffea arabica. Men gebruikt de bonen voor koffie. De bomen zijn vermoedelijk afkomstig van pitten, die destijds door de slaven van de plantages zijn meegenomen.

Kalebas (kabasi).

Groeit overal tussen de woonhutten en in verwaarloosde hoeken. Men maakt onderscheid tussen kabasi en pikien soepoen. Van beide soorten worden de houtige vruchtwanden voor allerlei doeleinden gebruikt, vooral voor vaatwerk (kommen, lepels) en als ,,koej” om de korjalen mee leeg te hozen.

\section{Kasjoen (kasoeng).}

Komt hier en daar voor, en levert gewoonlijk niet veel vruchten; deze worden vers gegeten, de pitten soms geroosterd als pinda.

\section{Mappa.}

Vermoedelijk een Tabernaemontana-soort (Apocynaceae). Niet zelden ziet men in Mei de vrouwen van de grondjes terugkeren met peervormige 
(tot $10 \mathrm{~cm}$ lange) gele vruchten, die zij verzameld hebben van een kleine bosboom. De vruchten worden vers gegeten; men klopt eerst met een stuk hout op de schil om het melksap hierin te concentreren, schilt de vrucht en het witte komkommerachtige vruchtvlees wordt gegeten. De smaak is fris zurig.

\section{Ricinus (karapata)}

Is in alle dorpen en vooral op afvalhopen te vinden. Het blad wordt gebruikt voor obia, de olie uit de pitten als een haarolie.

Peper (péprë).

Groeit als kleine struik bij de huizen of langs de rand van het dorp. Vooral de soort met kleine rode vruchten komt veel voor. De vruchten worden, in vleessoep gekookt, gegeten.

\section{Koemboe (komoe).}

Staat in enkele exemplaren in en langs de dorpen en in het bos. De pitten van deze palm worden graag gegeten, met warm water geweekt en gestampt tot koemboesoep. De vruchten zijn in Februari-Mei rijp. Een grote soort is patawah.

\section{Maripa (maïpa).}

Ontbreekt in geen enkel dorp. De vruchten leveren een wit, vettig vruchtvlees, dat vers gegeten wordt (Mei). De pitten worden gedroogd en met een steen stukgeslagen om de 3 kernen te verkrijgen. Na deze gedroogd te hebben (in de zon), kookt men daaruit een spijsolie.

\section{Awarra-palmen (awá).}

Staan in groepjes in elk Bosnegerdorp. De oranje vruchten die in Februari-Maart, soms ook in Juni, rijp zijn, worden vers gegeten, maar vaker gestampt in de matta, zodat het vruchtvlees tot een moes wordt. Men strooit hier suiker of suikerstroop op en eet het als een lekkernij (awá-popo).

\section{Pina-palm (apodong).}

Levert in April-Mei knikkergrote zwarte vruchtjes, die op de wijze als beschreven bij koemboe verwerkt worden. Deze palmsoort groeit op zwampige plaatsen in de bossen, in groepen bijeen.

Paramaribo, December 1952.

\section{S U M M A R Y}

\section{Agriculture AS APPlied By THE BUShNEgroes ALONG THE MARONI AND TAPANAHONI RIVERS}

During the Medical Scientific Expedition to the Southern BORDER OF SURINAM from February till July 1952, in order to get an insight into the medical problems of the interior, the opportunity was 
taken to investigate into the food supply of the Bushnegroes along the Maroni and Tapanahoni rivers. In this study agriculture, as applied by the Paramaccaner- and Aucaner Bushnegroes, and about which very little is known, is dealt with.

The Bushnegroes obtain their vegetable products by their system of shifting cultivation grounds, while some fruit trees are cultivated in the permanent villages. In the virgin bush they collect some palmfruits, of which they make drinks and palm oil.

The men cut and burn their grounds (each about two acres in size) during the long dry season (Sept.-Dec.). In the short rainy season following upon it (Dec.-Jan.), the women plant several crops (both annual and perennial) at the same time. Of these the harvest times differ widely, so that three months after planting time harvesting starts. Corn, ocras, peanuts, rice give their products in the first half year, while later on manioc and other tuberous plants, such as taro, yams and sweet potatoes follow. Bananas and plantains, sugarcane and pineapple are harvested in the second year.

Each plot of ground is used only for two years and after that it is given prey to the quickly overgrowing secondary vegetation. Each family usually cuts two grounds, one for the husband and one for the wife, so that with the ones cut the preceding year, each family has four grounds in use. These shifting grounds often lie far apart. This is not a division of risks, but a question of family property. The wife is allowed to cut hers only on the grounds of her people and the man to cut his only on his people's grounds. The different family-areas together form the piece of land on which a village can exercise its rights. The cultivation areas of the people of the villages along the river (see map) are assigned to the village captains by the granmans (chiefs) of the different tribes.

Much land is required by this system of shifting cultivation grounds. But owing to the curious laws of agriculture, the Bushnegro is obliged to stay within certain boundaries, which leads to exhaustion of the available soil. The use of the soil is intensified by the increase in the population, and is, besides, seriously threatened by the plague of the leafcutting ants (especially Atta sexdens). These ants principally occupy the secondary bush on the abandoned grounds, whence they undertake raids on the neighbouring shifting grounds. When an area is too seriously infected, the Bushnegroes avoid these ants - for lack of any remedy - and lay out new grounds in the virgin bush. As a result more and more secondary bush near the villages, occupied by leafcutting ants, becomes useless (,,ant-bushes").

Proposed measures to correct this bad state of affairs are: destruction of the nests of the Attd-ants and information on agricultural methods together with importation of other and better varieties of the crops used. In this way a more economical use of the grounds becomes possible and a greater production per acre is obtained.

A list of the crops grown by the Bushnegroes and their use is added, together with a statement of the fruit trees cultivated in the villages and of the fruits collected in the virgin bush. 